\title{
Governing social media: the emergence of hybridised boundary objects
}

\author{
Michela Arnaboldi, Giovanni Azzone and Yulia Sidorova \\ Department of Management, Economics and Industrial Engineering, \\ Politecnico di Milano, Milan, Italy
}

\begin{abstract}
Purpose - The purpose of this paper is to explore the processes whereby organisational actors can seize the opportunities opened up through social media, and the way in which the relative information is managed. This allows these actors to move their occupational boundaries, exploiting the information for performance measurement purposes. The investigation was carried out within an organisational setting, where most occupational dynamics take place. The focus was on the role of artefacts within these occupational dynamics and the analysis drew upon the notion of boundary objects.

Design/methodology/approach - The research was based on case studies involving two organisations that make use of social media within and across several departments. The authors conducted semi-structured interviews with social media managers, department managers, analysts and financial controllers and senior executives. The results of the qualitative analysis of the interviews were completed with secondary sources of information, company reports, communications, public policies, codes of conduct and social media platform analyses.

Findings - This paper has implications for accounting studies, showing how marketing and communications managers entering the field of performance management can take the lead in social media management by collecting information from social media, constructing indicators and gaining ground in several decision-making centres. The findings highlight the role of new artefacts and organisational roles, whose purpose is to build a digital community. This process involves crossing the boundaries between internal functions and the inside and outside environment, with a driving phenomenon becoming visible: hybridisation. Faced with this change, reluctant accountants with a traditional mindset are more likely to observe the process at a distance, focusing more on their routine operations based on conventional data.

Originality/value - This paper shows that information derived from social media is already a reality that has gained significance through the construction of boundary objects. The paper highlights a driving phenomenon that is emerging in the surge to occupy the organisational terrain for controlling social media: that of hybridisation. The concept of hybridisation is not new in management accounting studies, but in this study can be applied to carrying out a joint analysis on both the boundary objects and their organisational trajectory. In the context of social media accounting, hybridisation is of central importance if both actors and objects are to be effectively positioned at its boundary.
\end{abstract}

Keywords Occupation, Social media, Performance management, Management accounting,

Boundary objects, Hybridization

Paper type Research paper

\section{Introduction}

The digital world is part of our life. Wondering about the importance of social media nowadays is like wondering whether words are important. It is part of our life. In the past our chats took place in city squares, now we chat on Facebook [...]. Today digital and social media are everywhere (Head of Marketing, Utility).

While, few years ago, the above quote would have been seen as an enthusiastic comment made by a marketing manager, today this statement can almost be taken for granted. Social media have visibly exploded at personal and business levels, with an increasing number of

\section{Corresponding author}

Michela Arnaboldi can be contacted at: michela.arnaboldi@polimi.it 
organisations endorsing social media as a necessary part of their work (Richardson, 2009; Jin, 2012; Berthon et al., 2012; Roblek et al., 2013; Chikandiwa et al., 2013; Guinan et al., 2014; Gandomi and Haider, 2015; Manetti and Bellucci, 2016). Social media have a twofold use. First, they are considered as a channel for building a virtual community. This means that they must achieve a number of different purposes, which include issues of reputation and risk management, communication, marketing and sales, research and innovation (Bruhn et al., 2012; Field and Chelliah, 2012; Boyd and Gessner, 2013; Rust and Huang, 2014; Trainor et al., 2014). Social media are also a source of information, potentially capable of tracing peoples' individual characteristics, their comments and their relationships (Haefliger et al., 2011; Gamboa and Goncalves, 2014; Jeacle and Carter, 2014). With regards to other innovations in the field of information technology, new competences have to be developed that are at the boundaries of existing organisational functions. In the case of social media, a large pool of professionals are claiming the field: those involved in marketing and communications (Booth et al., 2016; Tymms et al., 2016) and in information technology (Eschenbrenner et al., 2014; Haislip et al., 2016), as well as the group of management accountants (Suddaby, Bruton and Si, 2015; Suddaby, Saxton and Gunz, 2015; Abeyesekera, 2015). Despite the increasing interest at a business and professional level, to the best of our knowledge, this occupational question in the domain of social media has yet to be covered in academic research. This paper aims at entering into these dynamics, by exploring the process through which organisational actors move their occupational boundaries and seize the opportunities opened up through social media and the way in which the relative information is managed. In doing so, the various actors enter the field of management accounting and performance management.

Empirically, this study is based on a multiple case study carried out within two organisations that have been using social media for more than five years in several departments across the organisations. For the purposes of our analysis, we drew on the notion of boundary objects, a concept developed by Star and colleagues to explain the nature of cooperative work among heterogeneous groups, even when there is no consensus among them (see Star, 1989, 2010; Star and Griesemer, 1989; Bowker and Star, 1999).

Our findings reveal a novel area of performance monitoring guided, in our cases, by the marketing and communications departments, as we find has happened in other fields (Oakes and Oakes, 2016). These departments build artefacts using social media data that are capable of supporting and leading activities such as innovation, customer management and the employment of talented people. Social media artefacts become objects capable of crossing organisational boundaries. Our findings highlight the existence of distinctive boundary objects, which are driven by hybridisation (Caglio, 2003; Kurunmäki, 2004; Dechow and Mouritsen, 2005; Miller et al., 2008; Chapman and Kihn, 2009; Kotb et al. 2012; Suddaby, Bruton and Si, 2015; Suddaby, Saxton and Gunz, 2015). Hybridisation emerges as central in promoting the use of data and exchange of knowledge. The focus on the actors' dynamics also allows us to see that the construction process has an enabling function. In turn, this sets a bond between the social media objects and their translation process, thereby opening broader theoretical considerations concerning the study of boundary objects. Faced with this change, reluctant accountants, those with a traditional mindset, are likely to observe the process at a distance and focus on their own business, concentrating on financial data and the financial cycle.

To present our arguments, the paper is organised as follows. The next section contains a review of the literature regarding the emergence of new professions for managing social media and their relative information. The third section provides the conceptual framework for this study. The fourth section contains a detailed description of the research methodology and approach taken for analysing the information. Fifth section is concerned with the case studies results, while the sixth and seventh sections address the discussion and conclusions. 


\section{Social media enable the emergence of new professionals}

The term social media refers to dynamic internet platforms and their ability to support interactivity and real-time communication (Kaplan and Haenlein, 2010; Kietzmann et al., 2011; Gruber et al., 2015; Floreddu et al., 2014). On the one hand, features of connectivity and collaborative technology are inevitably connected with the fact that users can interact, moving from a one-way to a two-way flow of communication. On the other hand, social media data are being produced continuously, and are available in real time (Kaplan and Haenlein, 2010; Kietzmann et al., 2011; Gruber et al., 2015), which means that data are generated at a higher rate than in the past. Networks, such as Facebook, Twitter, Instagram and YouTube fall under this definition, as do blogs. At a technical level, social media is a soft innovation, there being no dramatic discontinuity with the past. There has been, instead, a revolution at the social level (Kaplan and Haenlein, 2010). This is linked to the free and democratic access to global communication: every person with an internet connection can reach anyone in the world virtually. Social media started to spread through personal use, but now have become an instrument at business level (Richardson, 2009; Jin, 2012; Chikandiwa et al., 2013; Guinan et al., 2014), and was first used in the fields of communication and marketing (Gopinath et al., 2014; Hennig-Thurau et al., 2015). Several contributions show that they are now also used in other units or departments such as human resources, research and development and risk management (Bruhn et al., 2012; Field and Chelliah, 2012; Trainor et al., 2014).

We can see that two types of use have emerged, regardless of the organisational unit or process in which they are employed. The first, and more evident, is in the area of communication and promotion (Gopinath et al., 2014; Hennig-Thurau et al., 2015). Operations in this area involve proprietary accounts and webpages, i.e. the organisation's own social media, and social media providers. For example, LinkedIn is widely used for employment purposes, with corporations paying this provider to circulate their messages concerning new employments positions and so reaching a wider audience. Social media can also be used to find information about individuals and competitors. This function, often known as social media monitoring (Constantinides, 2014), is portrayed as a "panacea" by the consultancy industry (Kane et al., 2015). While social media can potentially give access to billions of accounts and their related data, in reality, for these data to be usable, several steps must first be carried out to acquire, clean, validate and then analyse the information, entering into the world of Big Data (IBM, 2014).

Both functions of communication and monitoring have opened the way to establishing large consultancy firms and new businesses (Booth et al., 2016; Tymms et al., 2016). The change is also affecting positions within an organisation, with various actors trying to seize the opportunities provided by social media (Cao and Manrai, 2014; Neill and Moody, 2015). The departments and roles most affected are in marketing and communication (Toledano, 2010; Wright and Hinson, 2012; Szabo, 2014), with "old" professional organisations claiming the social media terrain and providing support for facing the ensuing challenges (America Marketing Association, 2016; Chartered Institute of Management Accounting, 2016), and generating new professional associations for "social media managers[1]". In some cases, large associations have created new branches and/or dedicated groups, involving the areas of digital communication and digital marketing (Tiago and Veríssimo, 2014). Within companies, there is an ever-increasing number of positions in the areas of digital marketing and digital communication (Constantinides, 2014; Ting, 2015; Bologva et al., 2016). These positions are needed to handle the new type of media and communicate directly with an online audience, being capable of addressing the challenges of real-time communication and the need to engage with customers (Tench and Jones, 2015; Valos et al., 2016; Zamora et al., 2016). The recent streams in practice and in academic literature show that, in dealing with consumers, there is now a demand for factors 
that include storytelling, greater awareness, the creation of brand communities and augmented reality (Habibi et al., 2014; Scholz and Smith, 2016).

Another professional group in search of a role are the information technology experts, who draw on their technical knowledge (Fitzgerald, 2012; Swani et al., 2014). They have a broader role within the context of Big Data management, applying sophisticated methods to download data and apply analytics (van Dam and van de Velden, 2015; Ngai et al., 2015). Their function has become crucial in terms of retrieving data and transforming this information into a format that can be fitted into the process of managing performance within the different business units (Comuzzi and Patel, 2016; Hartmann et al., 2016). New roles are emerging connected to these topics, such as those of the chief digital officer, the data scientist and the data designer (Dumeresque, 2014; Constantinides, 2014; Ting, 2015; Bologva et al., 2016). Furthermore, the processes involved have led to specific technical tools and systems (e.g. Radian6[2]) being developed to monitor social media, which include data collection, data analysis, measurements and presentations directed at managers (IBM, 2014).

Finally, management accountants are entering into the world of social media, with professional associations such as the Chartered Institute of Management Accountants (Abeyesekera, 2015) and accounting associations across Europe and America asking for a role (IMA, 2015). These associations have addressed the urgent questions posed by the business world, being determined to consolidate business and theoretical knowledge into new methods and models that can be applied to this inter-disciplinary challenge. In 2015, the American Accounting Association dedicated a conference entitled "Accounting IS Big Data" to explore the influence of Big Data and social media on accounting practices. The interest in social media and its relative impact on financial professionals has been growing since 2011: "the management accounting functions will need to analyse and report real time information to support business growth, profitability and real time digital marketing" (CIMA, 2011, report).

Researchers in accounting and performance management have also stepped into this lively discussion about the implications of social media on reporting, performance measurements and dissemination procedures (Miller and Skinner, 2015). Miller and Skinner (2015, p. 222) have highlighted that "changes in information technology, the media and securities markets interact to affect the ways in which information about firms is produced, disseminated, and processed". Brown et al. (2015, p. 276) have, instead, concentrated on understanding how interactive technologies and real-time, low-cost information obtained from mobile communications can influence the decisions made by managers, leading to the creation of new boundaries and new professions.

These contributions have initiated a debate on the tasks, activities and professions concerned with the digital sphere, where the management of technology (here social media) is strictly related to the management of information. Although still under-theorised, the spread of social media already entails a hybridisation of professions (Caglio, 2003; Kurunmäki, 2004; Miller et al., 2008), with the generation of new roles, such as that of chief digital officer or data scientist (Dumeresque, 2014; Constantinides, 2014; Ting, 2015; Bologva et al., 2016). In this paper, with its focus on the specific aspect of social media measurement, our aim is to enhance the theoretical discussion which draws on the literature on boundary objects.

\section{Framework: boundary objects}

This paper is involved with investigating how the opportunities arising from social media, and the management of related information, are seized upon by various organisational actors. Management accountants potentially belong to this group of organisational actors, according to and encouraged by management accounting associations, yet little is known 
about what really takes place in practice. We will, hence, observe the micro-dynamics within their practice and the role played by their artefacts. There is no contradiction between our micro-analysis and the macro-level approaches, as the former is a research strategy used to understand how occupational communities work and how practice evolves within the organisational contexts (Bechky, 2003). In turn, this leads to a more detailed account of practice, as was recently set out in their accounting studies by Pollock and Williams (2015). They introduced a "third wave" in studies on the creation of expertise:

A "third wave" of scholars have argued for a shift of the focus of enquiry away from professional institutions towards: (1) Detailed examination of expert work and the processes by which expert status is achieved [...]. (2) More concrete investigation of the particular contexts, actor configurations and contingencies surrounding expertise formation [...] (Pollock and Williams, 2015, p. 1383).

We have followed this direction towards a more concrete and detailed interpretation, and in order to explore "how" this happens in practice, our empirical analysis draws on the boundary object literature (Star, 1989; Star and Griesemer, 1989). This lens has been used before in occupational and professional studies, allowing a micro-analysis of communities, practice and change to be carried out (Bechky, 2003; Levina and Vaast, 2005; Jarzabkowski and Kaplan, 2015; Marheineke et al., 2016), with emphasis on the role of artefacts (Bechky, 2003). Artefacts are the physical and visible enactment of the organisational actors' experience and rationality (Rose and Miller, 1992), but not all artefacts are boundary objects (Star, 2010). Boundary objects refer to artefacts that "are plastic enough to adapt to local needs and constraints of the several parties employing them, yet robust enough to maintain a common identity across sites" (Star, 1989, p. 393).

Although a number of studies have added additional properties to boundary objects (Jarzabkowski and Kaplan, 2015; Anteby et al., 2016; Marheineke et al., 2016), the three core and original characteristics are still those that distinguish them most effectively. The first property is interpretive flexibility, whereby boundary objects can mean different things to different people, because they are located between social worlds where they are not structured clearly. This is also seen as an important property according to studies on occupations and professions. Flexibility is important for boundary objects, for the purposes of implementation and use within processes, making it possible to reach people in various employment positions in different spheres (Orlikowski, 2007; Hsiao et al., 2012). Boundary objects connect actors within social networks and organisations by acting as a mutually beneficial learning and adaptation tool (Rathwell et al., 2015).

A second characteristic refers to the fact that boundary objects are tangible and visible, and must be respected and followed (Carlile, 2002). The classification provided by Marheineke et al. (2016) identifies the different kinds of emerging, pragmatic and semantic objects that influence the various actors within an organisation. The study highlights the tangible representation of an object, which can be a meeting or a virtual communication tool with specific rules. Other examples of the tangible side of boundary objects represent them in the form of tools (Arora et al., 2010), platforms within the processes (Saparova et al., 2013), guidelines and/or roadmaps (Fenton, 2007) and policies for specific actions or processes. Not all objects are material elements. For example, platforms and tools are digital objects that are installed physically on computers, while guidelines and policies are printed documents that employees must accept and sign.

The final defining feature is scale or granularity. Different groups cooperate to tackle the "back-and-forth between the ill-structured and the well-structured forms of the arrangements" (Star, 2010, p. 603). This movement between the different perspectives can either be scaled up or become standardised, with the result that boundary objects can change into something different, such as infrastructure or standards. Artefacts can be represented in the form of collaborative design systems with strict rules and settings 
(Wang et al., 2014), of information being translated or negotiated, of PowerPoint slides, video and audio channels (Li and Robertson, 2011) and even face-to-face real-time meetings (Alin et al., 2013). The scale of the documents or that of the different digital forms taken by the objects can vary from example to example. Sometimes the scale involves the whole company, when talking about rules and settings, or it can simply be a single meeting. It follows that there is significant variance between departments and work groups, although the strategy of many companies is to employ boundaries at all levels of communication and processes.

The choice of using the boundary object perspective was suggested by the requirement to study what happens at the boundary. This, in turn, is consequence of the novelty of studying social media management with a specific focus on practice (Levina and Vaast, 2005). The value of boundary objects is that they are, as stated previously, "both plastic enough to adapt to local needs and the constraints of the several parties employing them, yet robust enough to maintain a common identity across sites. They are weakly structured in their common use and become strongly structured in individual-site use" (Star and Griesemer, 1989, p. 393).

\section{Methodology}

The empirical part of the research took place in the starting of 2012. The appropriate cases were selected by searching and analysing preliminary information from secondary sources (traditional press, web sources and social media). This initial screening allowed us to identify companies, managers and experts active in the social media arena. We then contacted key informants to expand our initial sample, employing a snowball sampling methodology (Biernacki and Waldorf, 1981; Noy, 2008). In this initial case selection, we analysed the age of each social media platform (looking at long they have been visible on the web), the activity on social media (number of social media platforms used and daily activity on each) and the type of content communicated to the outside world. In all, 12 Italian companies were initially identified, three for each phase. After this first analysis, the authors contacted the social media owners to check whether they were prepared to take part in the study and the actual level of adoption. During this first phase, three companies were excluded, as their business either originated in or was shaped around social media and/or internet, creating a potential bias regarding our research questions. While providing initial information, two companies did not grant us access to detailed data. After this initial screening, we compared the remaining companies on the basis of two elements. The first element was how social media was used across the company, a question we asked during preliminary interviews with the social media owners. The managers' level of involvement in the use of data was, in fact, an element central to our research questions. The informants' perspective was crossed-checked with external data and verified with experts in their sector. The second element consisted in observing the action of organisations on social media, to monitor their activity. After this process, we selected two organisations. In this paper, the two companies are labelled as Art and Utility, from their business sectors. Table I provides a summary of the interviews carried out within the two organisations.

The empirical analysis of the two cases was based on two main phases: an in-depth online analysis and interviews. Online data were collected from multiple sources of information. For each company, we analysed official websites, relative brand websites, the companies' social media platforms, Facebook pages, Twitter accounts, YouTube channels and Wikipedia. We also looked at Facebook fan pages, fora and blogs. In particular, we observed the companies' social media online activity and interaction over a six-month period. Tables II and III give an overview of how widely used within the two organisations are social media to which the companies belong. Art is shown in Table II and Utility in Table III.

The second phase of the empirical analysis involved carrying out field visits and face-to-face interviews with the heads of the social media departments, the owners of the social media 


\begin{tabular}{llc}
\hline Company & Interviewees & No. interviews \\
\hline 1. Art & 1 \\
& 1. CEO & 3 \\
2. Director of marketing, sales and communications & 4 \\
3. Marketing and ticketing manager & 1 \\
4. Director of administration, finance, control and systems & 2 \\
5. Communications manager & 1 \\
6. Director of production and organisation & 4 \\
7. Former head of marketing & 1 \\
8. Director of asset management & 1 \\
9. External consultant 1 & 1 \\
10. External consultant 2 & 1 \\
1. Head of internal and external communications & 1 \\
2. Analyst & 1 \\
3. Head of communications & 2 \\
4. Head of global digital communications & 1 \\
5. Head of CSR & 1 \\
6. Person responsible for marketing and supply & 1 \\
7. Head of accounting finance and control & 1 \\
8. Person responsible for group planning and control & 1 \\
9. Head of risk control & 1 \\
10. Risk manager & 1 \\
11. Senior vice president, head of marketing & 1 \\
12. Head of Italian communications & 1 \\
13. Person responsible for Italian digital communication & 2 \\
15. Person responsible for Italian CSR & 1 \\
\hline
\end{tabular}

\begin{tabular}{|c|c|c|c|c|}
\hline Platform & Numbers & $\begin{array}{l}\text { Frequency of } \\
\text { messages }\end{array}$ & Themes of messages & \\
\hline Facebook & No. of likes $134 \mathrm{~K}$ & $\begin{array}{l}1-2 \text { per day excluding } \\
\text { weekends }\end{array}$ & $\begin{array}{l}\text { Messages cover the story of the } \\
\text { performances, more detailed information } \\
\text { about artists or interviews with them }\end{array}$ & \\
\hline Twitter & $\begin{array}{l}\text { No. of followers } 22.4 \mathrm{~K} \\
\text { No. of tweets } 12.2 \mathrm{~K}\end{array}$ & 1 per day & $\begin{array}{l}\text { Similar to the Facebook storytelling } \\
\text { about Art and its performance }\end{array}$ & \\
\hline YouTube & $\begin{array}{l}\text { No. of followers } 1.8 \mathrm{~K} \\
\text { No. of views } 1.2 \mathrm{M}\end{array}$ & $\begin{array}{l}\text { Once in couple of } \\
\text { months several videos } \\
\text { at a time }\end{array}$ & $\begin{array}{l}\text { Videos about performances or back } \\
\text { stages, interviews }\end{array}$ & \\
\hline Instagram & $\begin{array}{l}\text { No. of followers } 3 \mathrm{~K} \\
\text { No. of photos } 153\end{array}$ & 1 a week & Inspirational photos and short videos & $\begin{array}{r}\text { Table 1I. } \\
\text { Overview of Art's use } \\
\text { of social media }\end{array}$ \\
\hline
\end{tabular}

processes and the end-users of the information within the different departments. We decided to use semi-structured interviews with open-ended questions, as this was felt to be the most appropriate method for conducting a detailed investigation of the process to adopt social media and observe the approaches implemented. We interviewed 25 people. Some informants were interviewed more than once, giving a total of 36 interviews. Each interview lasted between 60 and 90 minutes and was then recorded, transcribed and analysed. The fact that informants were included in the study made it possible to saturate the understanding of the social media trajectory. To ensure that the information was reliable and mitigate any bias, we also analysed secondary sources of information, company reports and communications, public policies and codes of conduct. 


\begin{tabular}{|c|c|c|c|}
\hline Platform & Numbers & $\begin{array}{l}\text { Frequency of } \\
\text { messages }\end{array}$ & Themes of messages \\
\hline Facebook & No. of likes $44 \mathrm{~K}$ & $\begin{array}{l}1-2 \text { per day excluding } \\
\text { weekends }\end{array}$ & $\begin{array}{l}\text { Aligned with real life, currently the } \\
\text { UTILITY bicycle and "Fuori Salone" } \\
\text { (= beyond the exhibition) and } \\
\text { "Salone mobile" (= mobile } \\
\text { exhibition), Utility sponsors "friends" } \\
\text { ("Amici"), promotes digital bills } \\
\text { ("Bolletta elettronica"). Responses } \\
\text { from the people are related to their } \\
\text { problems. UTILITY answers asking } \\
\text { them to connect their CRM }\end{array}$ \\
\hline Twitter & $\begin{array}{l}\text { No. of followers } 12 \mathrm{~K} \\
\text { No. of tweets } 2.5 \mathrm{~K} \\
\text { No. of likes } 1.5 \mathrm{~K}\end{array}$ & $\begin{array}{l}1-2 \text { per day excluding } \\
\text { special occasions when } \\
\text { can be up to } \\
10-20 \text { messages }\end{array}$ & $\begin{array}{l}\text { Very focused on utility themes and } \\
\text { new renewable energy, like Wind } \\
\text { power, university collaborations and } \\
\text { can disclose general-type information } \\
\text { about the company, such as its } \\
\text { EBITDA }\end{array}$ \\
\hline LinkedIn & No. of followers $89 \mathrm{~K}$ & Every 3rd day & $\begin{array}{l}\text { Mirroring Twitter with more text and } \\
\text { pictures, but themes are the same }\end{array}$ \\
\hline YouTube & $\begin{array}{l}\text { No. of followers } 6.5 \mathrm{~K} \\
\text { No. of views } 9 \mathrm{M}\end{array}$ & $\begin{array}{l}\text { Once or twice a } \\
\text { month several } \\
\text { videos at a time }\end{array}$ & $\begin{array}{l}\text { Start-ups, education, description of } \\
\text { new projects }\end{array}$ \\
\hline Google+ & $\begin{array}{l}\text { No. of followers } 386 \\
\text { No. of views } 379 \mathrm{~K}\end{array}$ & Every day & $\begin{array}{l}\text { Messages are related to how the } \\
\text { company works with news about } \\
\text { growth and changes }\end{array}$ \\
\hline Instagram & $\begin{array}{l}\text { No. of followers } 11 \mathrm{~K} \\
\text { No. of photos } 722 \\
\text { Av. no. of likes } 30\end{array}$ & $\begin{array}{l}2 \text { photos or videos } \\
\text { per day }\end{array}$ & Aligned with Facebook posts \\
\hline
\end{tabular}

The analysis was carried out by triangulating the data collected (Denzin, 1978; Jonsen and Jehn, 2009), using the preliminary framework as our theoretical reference. The first step in the analysis consisted of coding the interviews, highlighting the key issues that have an effect on both the adoption and use of social media and on the actors' roles and their strategies. The boundary objects were also identified at this point, together with how they were used and what they were used for. During this initial phase, we first carried out a within-case analysis and then a cross-case comparison. It emerged that the purpose or reasons for adopting social media are among the aspects that are most important for interpreting the findings, since these factors influence the actors' roles, together with the strategies and objects that came into play. After analysing the interviews, we performed a cross-source triangulation, adding elements from secondary sources to increase the overall reliability. In this phase, two methodological instruments were introduced to help map the information: tables summarising the results and a process scheme containing the timing, when relevant, and the actors' roles. Table IV presents an extract from this analysis. Theoretical matching was finally applied to analyse whether the defined concepts and relationships were present (or not) in literature and how our results contributed to boundary object research and management accounting studies[3].

By cross-checking the previous literature, we assigned labels to concepts or attributes seen as new compared to those found in previous contributions.

\section{Social media control in action}

This section illustrates the results of the two case studies. In both cases, the organisations had gone through a transition period for the management of social media. 


\begin{tabular}{|c|c|c|c|c|}
\hline Issue & Dimension & Source & Data & \\
\hline \multirow[t]{3}{*}{$\begin{array}{l}\text { Social } \\
\text { media } \\
\text { purpose } \\
\text { (Art) }\end{array}$} & \multirow[t]{3}{*}{$\begin{array}{l}\text { Financial } \\
\text { sustainability }\end{array}$} & $\begin{array}{l}\text { Interview } \\
\text { statement }\end{array}$ & $\begin{array}{l}\text { Marketing and Ticketing manager: "Social media were and are our } \\
\text { shop window. We are trying to communicate well, but there is still } \\
\text { the sense that we are also trying to sell tickets. We have so many } \\
\text { shows and communication is very difficult" }\end{array}$ & \\
\hline & & $\begin{array}{l}\text { Social } \\
\text { media } \\
\text { data }\end{array}$ & $\begin{array}{l}\text { Facebook: "Monday feels less like Monday with jazz! The event } \\
\text { kicks off on December } 5 \text { th at [...]" (2 December 2016) } \\
\text { Twitter: "Beginning tomorrow \#5-December \#MitJazz } \\
\text { Festival, presenting the best of Italian \#jazz over \#three-days" } \\
\text { (4 December 2016) }\end{array}$ & \\
\hline & & Reports & Interactive worksheet for reporting and discussion purposes & \\
\hline \multirow[t]{2}{*}{$\begin{array}{l}\text { Social } \\
\text { media } \\
\text { purpose } \\
\text { (Utility) }\end{array}$} & \multirow[t]{2}{*}{$\begin{array}{l}\text { Transform } \\
\text { image } \\
\text { perception }\end{array}$} & $\begin{array}{l}\text { Interview } \\
\text { statement }\end{array}$ & $\begin{array}{l}\text { Communications manager: "We start with four pillars: Content: } \\
\text { inspire through story-telling; Channel: all the channels as each will } \\
\text { be managed at global level and at local level; People: we want } \\
\text { 'to spread digital culture' internally and externally; Consolidate our } \\
\text { reputation: our positioning must reflect us being an innovative } \\
\text { company" }\end{array}$ & \\
\hline & & $\begin{array}{l}\text { Social } \\
\text { media } \\
\text { data }\end{array}$ & $\begin{array}{l}\text { Facebook: "Our company highlights the talent of the young people } \\
\text { at the National Academy of Santa Cecilia" ( } 6 \text { December } 2016) \\
\text { Twitter: "The company opens power plants to visitors. Russia's } \\
\text { Open Plants received an award at [...]" (5 December } 2016)\end{array}$ & $\begin{array}{l}\text { Table IV. } \\
\text { Exemplary extract } \\
\text { of pattern analysis }\end{array}$ \\
\hline
\end{tabular}

\subsection{Art}

Art is a non-profit organisation founded in the 1940s that operates in performing arts within a large Italian city. The founders wished to create an institution that would be an essential public service supported by the state and local authorities. Art was established with the slogan "Art for Everyone" and today it still fully embodies its aim to put on quality performances for the widest possible audience. Art has several venues across the city and, in recent years, has included an international and inter-disciplinary dimension, presenting itself as the ideal citizen and a European centre of culture. Art's stages set the scene for drama and dance performances, exhibitions and film festivals, round-table debates and cultural study meetings. Art's income comes from three sources: government, sponsorship and ticket sales. Over the past two decades, Art, as all other Italian art organisations, has had to cope with a progressive decrease in public funds. While, in the 1990s, public financing made up nearly 70 per cent of its income, recently this has dropped to about 40 per cent. The loss of public funds was covered in part by sponsorships, but mainly through tickets sales, as highlighted in the comment below:

The government is cutting our funds year on year and there is no sign that the good times will ever come back. We have had to search for sponsorship, but now even companies and foundations are more careful with their money. So our only way is to bank on ticket sales, but still keeping prices at a level that does betray our motto [Art for Everyone] (Administration, Finance, Control and Systems Director).

Art has about 300 employees and a total income of nearly 19 million euros. The CEO, who is also the artistic director, is joined by four first line managers for the areas of production and organisation, in charge of the preparation of performances; administration, finance, control and systems (finance for brevity in the following), with six units for administration, management accounting, human resources, purchasing, legal issues and information systems; marketing, sales and communication, including marketing and ticketing, promotion towards individuals, promotion towards organisations, publicity, special projects (mainly for children and in schools), art material archive; and asset management, for the four units of tangible asset management, door-keeping, security, maintenance and logistics. 
At present, social media is managed through the marketing, sales and communications department (marketing for brevity). Five people in five sub-units work on social media, with help from an external agency. Social media was introduced by the former head of marketing, who is also considered to be Art's marketing initiator:

The former head of marketing invented marketing here, most of us here must thank him (Marketing and Ticketing Manager).

Art belongs to three social media, Facebook, Twitter and YouTube, joining them one at a time from 2008 onwards. Facebook was its first social media and was initially treated as a second website, as described by the marketing and ticketing manager:

At a certain point, according to experts and gurus, Zuckerberg [Facebook founder] wanted all other websites to die, as he wanted the Facebook page to be the official entry point for every company. It did not happen and in my opinion it won't happen. We have now started to change our approach but we are not yet satisfied.

Twitter was introduced in 2009 and YouTube a year later, although with less emphasis.

While, at the beginning, actions on social media were unsystematic, since 2010, Art has started to programme its actions on the different media and has employed an external agency specialised in social media communications:

[...] to give you an idea, for Facebook we post at least 3 times a day, 7 days a week at 11 am, 5 pm and $5.30 \mathrm{pm}$, unless there are specific events or initiatives. We have a defined editorial plan for the other social media (External Consultant).

Initially, the social media strategy was to support traditional media initiatives and marketing campaigns, then Art moved towards a more methodical process, with dedicated monthly resources. This marked the first step in expanding the scope of social media management within the organisation. Social media became something to be planned, absorbing resources and potentially with a positive impact on the organisation. In this perspective, Art decided to invest in an online social monitoring system, which was acquired externally. The tool was a web-based system, linked to proprietary social media, with updates in real time and the possibility of monitoring the number of comments, followers and sentiment. The tool was welcomed enthusiastically by the marketing and communications managers, who saw its possibilities in terms of observing customers and then acting online more promptly. However, the object acquired proved not to be satisfactory:

Our web social monitoring is invaluable in terms of seeing the real-time reach of our promotional actions on Facebook and Twitter. I can post a video of actor X and immediately see our community's reaction. Unfortunately, however, we cannot integrate our action calendar into the system and so cannot get a broader view over a week or a month (Communications Manager).

I expected something more [from social monitoring] on our community with links to their purchasing habits or even personal interests. What I mean to say, it's better than nothing, it is useful to gauge community sentiment and engagement, but the indicators are quite simple and we just cannot work with this system (Marketing Officer).

Both actors highlighted the rigidity of the system and that it cannot be integrated with other analyses and variables.

To avoid social media and relative monitoring turning into a mere side matter, the initiator started putting it on the agenda for senior executive board and marketing meetings, both held on a weekly basis. The senior executive board meetings are attended by the CEO, the production director, the $\mathrm{CFO}$ and the heads of marketing and communications, with major issues and events being discussed. Marketing meetings are, instead, used to discuss short-term sales and promotional strategies and what material to circulate through the various communication channels. In both cases, an artefact is used to lead the discussion, scheduling. Scheduling is a 
structured document available online, which contains the entire programming plans for the upcoming two years. The document consists of several layers, with different levels of detail, and includes all the resources managed, such as the tangible and intangible assets, income and costs. Scheduling includes a forecasting section, which goes into daily detail when an event is approaching. Scheduling also includes the company's actual results in terms of costs, revenue and tickets sold (no assets), allowing the system to build graphs and tables showing the variance between actual results and budgeted figures. The most developed part of scheduling concerns sales and is updated in real time with links to the various selling systems (online and physical). Marketing and promotional actions can be viewed in this section, to see the impact on sales.

Although the document was created by the marketing unit in 2011, it is now the main planning and management instrument within the organisation and nearly every informant spontaneously mentioned it as being crucial, including the heads of administration, finance, control and systems (for brevity, CFO):

We all use Scheduling as a monitoring system and we have all revised it according to our needs. For me, it is important to cross-reference the items included and check the overall coherence with the annual budget and the financial statements (CFO).

Social media is included within the scheduling plans as a promotional action, and are represented by "coloured" dots that refer to the date in which they are carried out. They are included in the same graph as sales (budgeted and actual). Although the company sets no direct relationship between sales and social media actions, this visual choice indicates the original thought process behind the use of social media: they were seen as a tool to promote the organisation and then sell its products, as explained in this comment:

Our customers cannot buy tickets on Facebook or Twitter; I want to attract them with what we offer, wet their appetite and point them towards our website, where they can buy tickets.

The emphasis on social media as a sales and marketing instrument is also apparent in their annual report, in the CEO's introduction:

For 2015, our primary objective is to consolidate our results in marketing and communications. The excellent results achieved in web marketing on social networks (more than 120,000 followers (subscribers), on our web site and through the initiatives offered to the art community, which has over 130,000 members, confirm that we made the right strategic choices (from the Annual Report 2014).

The link between social media and sales was initially seen jointly as a strength and a weakness both for the head of marketing and in terms of expanding the domain of social media. It was a strength because of having an additional sales channel, with low costs, and this helped to define social media as an important factor and deserving of attention and resources. It, however, became a weakness as everyone, even the initiator himself, started to look for a correlation between sales and social media and so always find new ways of "turning a follower into a theatre-goer". It is here that other artefacts started to enter the picture, although only for the marketing meetings, in the form of social media monitoring, consisting of statistics and analysis obtained from social media and even images obtained from the social monitoring tool (see Figure 1 as an example).

At the beginning, they used simple statistics about the size and vitality of the communities, discovering that they have a large social community, especially on Facebook, which was, however, very nearly silent. In 2014, they asked the external agency responsible for social media promotions to prepare several specific reports using more sophisticated tools. The former head of marketing wanted to search for a solution to measure social media at individual level:

I would like to know who our social media users are; some of them we know are our subscribers, as they use the same user ids for Facebook and for making purchases, but all the others are unknown. It would be great to have an integrated system to group our users together (Former Marketing Manager). 
Figure 1.

Social media map inserted in art reporting

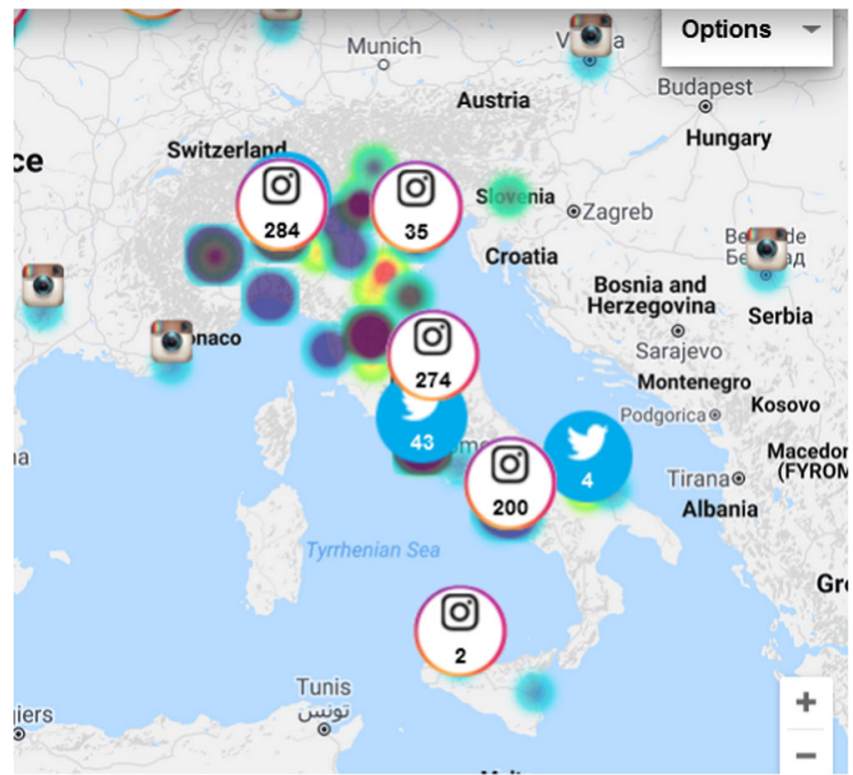

When he left in 2015, the "results of social media" (informant's words) were uncertain and the matter passed to the new marketing manager, who then wanted to change the social media strategy:

Social media are not a sales channel, for this we have our website. I want to use social media to create brand awareness and share material. If you look at our Facebook page, there is nothing about our organisation, our people, you only see our events. It is still just like our website (Director of Marketing and Communications).

In the search for a new strategy, social media monitoring became more important and a topic of greater discussion, pushing the external agency into exploring social network issues in greater detail:

We monitor our actions on social media, if we paid for posting a promotion, we want to know what happened after its launch [...]. Whether or not this action [the paid post] brought in results, how it converted into tickets sold, should we continue or should we stop or maybe invest more. During the meetings with our agency, we discussed what the conversion rate would be, should we invest 100 euros in the post-link, whether it would make sense or should we switch to another channel (Marketing and Ticketing Manager).

Overall monitoring is discussed during the weekly marketing meetings with the particular involvement of the marketing and ticketing unit and the promotions unit, with both having access to the company's dashboard. This dashboard was recently introduced to the senior executives' meeting through scheduling. A new sheet with a link to the online system was added, and this contains the key performance indicators for social media actions and results. Alongside the traditional indicators used for social media, such as the number of likes and increase in followers, the system proposes the conversation rate linking the number of tickets purchased to a post that has been paid for.

The social media monitoring sheet is considered as a "control system" by the people in marketing, and the marketing director wants this to be the general perception throughout 
the organisation, with simplified data-building categories (social media, traditional media, direct mailing, etc.):

This [referring to the Scheduling sheet] is a control system. We have to group data into macro categories; if there is too much detail or too many categories, people don't understand. We have added links to the same graph online; this not because we are lazy, but this dashboard is the helm we use to guide our decisions on a daily basis (Director of Marketing).

Other (non-marketing) informants, the asset management director and the production and organisation director, were positive about the new instrument and the possibility of seeing an evolution in real time. Social media monitoring allowed them to reflect on their social media strategy and the need to use their community not simply for sales purposes:

Looking at the level of participation [number of comments and likes on Facebook] and the reaction to our posts [average number of comments and likes for a post], it is clear that we need to change something, I'm convinced that we need to add more material about Art (Asset Management Director).

The director of production held a similar position, mentioning the cultural role of Art:

The government has cut funds and does not realise the damage it has done, but we need to remember our cultural function. Of course, sales are important, but we need to say something more (Production and Organisation Director).

Following this stimulus, the marketing director decided to run meetings about content and material involving other departments, changing the way reporting is carried out to how "content" is selected and defined:

We must recreate the conditions of speaking to an audience. We have to understand our past results, not by only looking at generic data on sentiment. We have to concentrate on the quality of things (Marketing and Ticketing Manager).

When thinking about how best to proceed, the marketing director felt that the work of monitoring social media, and more especially the changes made to data categories, highlighted the corporate desire to examine results at individual level and trace the "success" of any given content:

It would great to go down at the individual level and to know the success of our content-based strategy. Who likes what? For example, I'm convinced that videos of the back stage are great, but I need also to convince the people in security. It was very hard just to get one (Marketing Director).

Categorisation is a variable where great attention is placed on attempting to obtain an enterprise-wide instrument. This was also the thought of the finance director, with her work to prepare the overall budget and financial reports:

The social media monitoring dashboard and all our data are grouped according to the detail required for the budget, for example by type of tickets (Marketing and Ticketing Manager).

Notwithstanding this alignment effort, the finance director clearly stated that this information is outside her competence and does not directly influence her planning and monitoring work:

Data are interesting, but it is always a matter of time; I have to check our financial statements and be sure that our income covers our costs. Then I have to prepare the financial reports for people inside Art, for the board of directors and also for the government and our sponsors. At the moment, I have no time to spend on other data (Finance Director).

Accountants concentrate on merely balancing several types of performance at the same time and on distributing the available funds. 


\subsection{Utility}

The Utility is a large player in the Italian energy market. The company started to explore social media in the late 2000s within its internal and external media unit, launching an initiative on its Italian site under Communications. At the beginning, social media activity was entrepreneurial: the head of the unit (who became the head of the Digital team), used his personal blog to establish a more open online dialogue with the outside community, applying his skills from his previous experience in a telecommunications company:

My blog is a sort of connection point between the company and me as director of Internal \& External Media, giving me the possibility of being more open and speaking about something in a free way, as a connection point between the company and the external world; working inside, but being an individual speaking through my blog (Former Head of the Digital Unit).

The thought process behind this first initiative was in line with the fundamentals of social media: an open and non-purposive community where people can connect. The initial social media-based strategy was quite limited and managed within the communications department. The initiator, however, soon showed that he was able to create a different voice, which could be useful in moment of crisis. For example, through his blog, the initiator was able to moderate comments against a Utility promotional campaign, deploying his personal network of contacts. This and similar events gave him internal recognition and he started to involve other people in the process of communicating through digital channels.

Relative information was shared with other experts at daily meetings, during which they decided "how to connect our corporate blog, website and my blog". The media portfolio became their boundary object. Their work was changed and shaped through an adaptive strategy with no clear general goal, apart from engaging the outside world, regardless of whether the people they were engaging with were customers or not.

The results achieved during this embryonic strategy were shown to the person responsible for Communications who decided to establish a formal "Digital" team of seven people, with the initiator at its head. With the Digital team, it was possible to manage more social media platforms, including Facebook, Twitter and YouTube. In addition, the Digital team was given a formal, twofold, target:

On one hand, they want us to spread brand awareness for the company's products and improve its reputation; on the other, the aim is to understand our customers better and involve them in the initiatives launched by the Marketing department (Former Head of Digital).

The team was able to take control of an empty space within the organisation, given that nobody, even in marketing, was looking at social media:

The Marketing department does not have either a unit to manage social media or a more or less digital environment; we are helping them in terms of strategy and in part for the execution, especially concerning the first level of interaction with end-customers (Former Head of the Digital Unit).

While the first goal was similar to what had been carried out previously and could be managed within the communications unit, the second goal entailed something new: the management of information for business purposes. The Digital team had the challenge of adopting a more methodological vision, where listening and measuring became important. Furthermore, they had to cross the boundary of Communications and start a dialogue with several departments interested in receiving the information they could provide.

As was the case with Art, Utility also decided to buy the licence for a web-based monitoring system. The system adopted here was more refined than that used in Art, with personalisation features. Utility's monitoring tool allowed them to observe trends affecting their own proprietary accounts and also to monitor trends and conversations on other social media accounts. The initiator gave several business units access to the 
application but, after the first months, he realised that they were only making marginal use of the system:

We bought the best tool on the market, but our managers did not use it. You can actually monitor everything you want by putting in the right key words. It was probably just too complicated and people finished up by getting lost in the application (Digital Team Analyst).

To address this situation, the initiator decided to start a process of personalisation, with the support of the external web tool provider. The departments were involved in one-to-one meetings, in order to glean their specific needs and see what knowledge had to be translated for the requirements of monitoring. The Digital team used this process to develop a complex measurement system with an online interactive dashboard for visualisation purposes. Sophisticated automatic systems were implemented to collect and analyse specific data obtained from social media and then convert them into performance metrics. These performance measures were circulated to the various levels within the Communications and external relations departments and to other departments and senior managers, by means of daily, weekly and monthly reports.

In preparing these reports, the Digital team acquired new skills, learning how to analyse textual information starting from a large and awkward number of comments. This awareness and the positive response from marketing induced the Digital team to offer their reports to research \& development and human resources:

We have market reports that are sent directly to the head of Marketing, we also have corporate reports that are sent to the heads of all the functional divisions, I mean External Relations, Auditing, Security and others, it's long list, with no filter. For our corporate departments, it is a daily report, and also for marketing and renewables, as the Head of the Green Power unit has asked for a daily report, without filters. The market report is daily as well (Former Head of the Digital Unit).

These monitoring reports were a second boundary object and offered great flexibility, due to the almost infinite possibility of searching the web for whatever the different departments wanted. Furthermore, since it was possible to link specific comments to specific users, this brought an additional sense of the tangible to a company where information mainly comes from anonymous surveys.

Having started the process as an entrepreneurial initiative, in two years, the initiator was able to spread a "culture of social media" (informant's words), raising interest first in communications and marketing, and then also in other departments. In 2014, the team consisted of 35 people, seven dedicated to the Italian context and the rest managing social media for the whole group, in other countries. In spite of this expansion, the initiator maintained his researching stance:

Consider that we are doing a lot of research (pilots \& trials) with external partners. At this stage, we are working on the semantic web, the last was launched two years ago and was the open data platform, and we were the first company in Italy to have published 680 data sets in open source (Former Head of the Digital Unit).

Despite working with external partners, which was not the case in Art, Utility decided to employ data analysts, which allowed them to acquire and retain knowledge about their data, after an exploratory phase carried out with their external partners. For example, the Digital team developed its own methods to elaborate and choose from data provided by the external agency in the form of KPIs:

Reputational KPI with two types of indicators, the first is a quality indicator, the second is visibility. The first indicator can be negative, neutral or positive. The second depends on the visibility of the company, looking at all traditional web material - web 1.0, social networks, blogs, videos and images. Aspects such as how visible do I want to be and what level of quality do I want are set within these formats and platforms (Former Head of Digital). 
These data were disseminated through weekly and monthly reports; at the Italian site these were sent to all departments, at world level, to Communications.

The enterprise-wide interest progressively changed the way social media were used. From being non-specific, it became multipurpose, involved in promotions and sales for the marketing area, idea screening for research and development, and searching for talented potential employees within human resources.

This situation changed in 2014 when a major reorganisation took place and a new CEO was appointed. The new CEO wanted to make deep changes to the company that would also affect its image and reputation across the world. As part of this strategy, he employed a new communications director with significant experience in various sectors all over the world. He was put in charge of a new global communications department and several people were brought in from outside the company with wider international vision. The former Digital team was integrated within the company, but none of the team was given a place in the new global communications division. The data analysts were moved to the marketing department in the local Italian unit. The head of the digital unit was sent to head up the newly established department for energy efficiency and public lighting solutions, because of his personal interest in the subject and knowledge of efficiency management.

A new head for the digital unit with experience in brand management was employed from outside the company; she put in place a team of ten people supporting the work of the global communications department. During this period of transformation to the local units, in Italy, to give one example, the company created a series of similar positions where people were responsible for digital communications published on the Italian social media pages. In addition, within the global and local marketing departments, special attention was paid to online marketing activities that involved dedicated people. As highlighted in the Results section, these people work with the global and local communication departments to define the specific tone of voice to be used, ensuring that external communications at all levels are recognisable and everyone follows the new rules.

In this new two-level structure, the global communications department controls and develops global communications and analysis, while the local units follow the same guidelines, adding country-specific content. The new approach to social media at the corporate level is said to have a precise goal: that of improving the company's global image and reputation in terms of reach and coherence. The informants reiterated several times that issuing global policies and guidelines was central to their new strategy and objectives:

Clearly, to earn trust and credibility, you must ensure continuity in user experience and a very solid identity between all your different parts, and you must then spread the same message in the right way, without going in different directions, use the same tone of voice and propose the same contentbased strategy. This is a titanic effort, but allows you to earn trust (Communications Manager).

The local team is responsible for collecting and analysing their information in a specific format and propose improvement to the global communications department in terms of guidelines and/or analyses.

This new approach was soon introduced within the various departments, which had to enforce the formal programme, as explained by an informant from marketing:

There are procedures, guidelines, there are deadlines for the activities [...]. There is no space for any free initiative, listening is done in a systematic way, it is not that someone can get up in the morning and say: "Well, let see what's happening on Facebook, and what they are saying" or "Let me examine some network results and see what they tell me". We have a methodology, clearly the more time passes, the more structured these methods become. These activities [on social media] are an integral part of all our activities and therefore should be structured (Head of Marketing).

The comment above shows the strict relation between plans, action and results within the social media sphere. Sometimes they overlap due to the immediacy of the interaction. 
This was understood by the new communications director, who adopted a new social media monitoring tool to assess and communicate his results throughout the company. In social media monitoring, as in the social media strategy, the new approach is less exploratory, and involves choosing the most simple solutions available on the market and pushing for standardisation.

The results are promoted internally with much emphasis.

In searching for top-level recognition, a large hybrid pool of traditional economic and financial data was investigated, without setting any direct correlation. The head of communications gave a detailed explanation about the importance of communications and influence on the market and the need for a correct and coherent communication across all media channels:

Communicating about sustainability and innovation is very important from a financial point of view. If we start with the overall value of the company on the Milan stock market, and it is 38.2 billion euros, how does the market arrive at that value of 38.2? It's a simple mathematical thing. They take the earnings. Our net income for the year 2015 is 3.0 billion euros. We, Communications and Innovation \& Sustainability, do not control that value. Our colleagues from Production and Distribution are in charge of the amount. What are our stockholders doing? We are talking about a multiple, a price per earning multiple (in our case 12.7). This number is really a gut feeling for each stakeholder and each has a different idea. Someone feels it is a little bit low, someone else that it is a bit steep. That's the reason why you have a market: someone makes and someone buys, you need two different opinions. Someone thinks it's too light, someone that it's too heavy. Our job is to influence this 12.7 , the gut feeling of the investor. How do we do that? We make investors think that the management team is a genius, we make them see that the cash earnt in our business is very secure, we make them think that the innovation within our business is fantastic. So, all this stuff goes into this 12.7, it is made up of these things: visibility of cash earnings, growth prospects of the company, macro-economic risks etc. (Head of Global Communications).

Another difference is the higher desire to promote the results internally, in order to gain attention and recognition at senior level:

I'm thinking about the night we started the campaign for our new brand, in Madrid, on January 26, with real-time two-way interaction, all totally new for the company, and we reached an incredible 16 million people in 24 hours. This was an unpaid campaign. We reached a third of Utility customers. We showed our CEO the data on engagement for our new brand and we outperformed the final World Cup football match in the USA, and the San Remo musical festival which was running over the same period, both events had fewer viewers (Communications Manager).

Although the end purposes are different, there are similarities between the new global communications team and the old Digital team. This is the desire to set up an inside-outside community that involves "true workers from the inside" (informant's words) and "influencers outside":

We work with and identify the influencers and can talk to them. Utility has one great aspect: first it does and then it tells [...]. The press releases do not quite agree with this. Social media were used to spread news in a sterile manner [...]. We want to use a journalistic style and make brand-related information and material both engaging and inspirational. Therefore, influencers can see the extent of what we are doing. This is work of the Digital PR people, together with the data analysts. This means that data analysis, web monitoring and Digital PR activity will allow us to leverage on all of this (Communications Manager).

Both workers and influencers are expected to become ambassadors of the company in the social media arena and its defenders on social media in moments of crisis.

Other departments are involved directly or indirectly in social media, including marketing, customer care, accounting, finance and control (AFC), human resources, internal auditing and risk management. In the risk management department, social media is out of the institutional 
scope, while, at the personal level, managers use social media to share information, receive updates from the field and remain in contact with colleagues on LinkedIn:

Social media have not yet entered the world of risk as part of its mission (Head of Risk Control).

Currently, we searching for two employees for one of our departments and I saw that we [Utility] have put an advert on LinkedIn. I use Facebook to find the most recent information on risk management, announcements of changes to laws or new regulations and share them with my colleagues (Risk Manager).

The head of risk control indicated that, from the perspective of risk regarding social media especially at individual level, advice is included in the company's ethical code. The ethical code is similar to a boundary object artefact.

In contrary, the head of AFC clearly stated that they do not take social media information into consideration, and the planning manager confirmed that social media activity was not of primary concern to their department during the period of evolution and reconfiguration:

The world of social media for now is not our business. We are a bit behind in the sense that for us it is difficult to capture the answers of the online community and then use them to guide and drive our business. It is clear that our analyses and the strategy are not driven by indications of this kind (Head of Group Planning and Control).

\section{Discussion}

In the previous sections, we presented two cases where companies made an extensive use of social media and associated information throughout their organisations. The cases show that the companies used social media as a means to expand their occupational boundaries. They achieved this outcome by developing two social media processes that had emerged from previous studies (Swani et al., 2014; Ngai et al., 2015). The processes were communication and promotion (in terms of content and technology), and social media monitoring, which involved entering the field of performance management. At Art, social media were originally introduced and developed within the marketing department. Social media were seen internally as the key for achieving financial sustainability, allowing the company to strengthen a major line of income (ticketing). More recently, the meetings held to discuss social media have turned into an opportunity for discussing Art's strategy. Two strategic issues emerged in particular. The first highlighted the need for Art to regain its "original" cultural role and use social media as a vehicle to transmit "cultural content", without always fixating on sales. The second involved the trade-off between quantity and quality in theatre performances and the associated material and/or content to be placed on social media.

In the case of Utility, there was greater discontinuity, following a change in governance to the area of social media. Regardless of this change, there was a clear train of expansion. In the first phase, the initiator was able to set up an entrepreneurial initiative with a team of 35 people, thereby seizing an empty space within the organisation. The team worked both as a service unit - for example, in marketing and customer care - and also as a panel of innovators, testing new methodologies and developing internal competencies. After the organisational transformation, the skills and objects that had been created became valued within other departments. In the second phase, social media management was placed under the new global communications department and its geographical scope expanded to take in the entire corporate group. This new department was assigned the explicit objective of creating a coherent image throughout all departments and countries. A new head of the digital unit was brought in and she set up a team of ten people at corporate level, supported by local units spread across the world.

In term of competences and tasks related to social media, the two cases show some level of diversity. Art favoured employing external consultants to manage both communications 
and data. This aside, a key figure emerged throughout the process of developing social media, that of the marketing and ticketing manager. He was the mediator (Latour, 1984) between the external consultants and Art. His direct experience with regards to scheduling, a central decision-making object, gave him the knowledge to translate social media monitoring data into usable information, and he was able to adapt and change categories based upon his understanding of the various managers' needs. Utility also decided to bring in external consultants, but the organisation also developed a number of internal technical skills in parallel, especially in the area of data analysis. This helped the company to introduce a critical approach in their dealings with consultants and external partners. It follows that the initiator was a mediator during the first phase, even though he never set out explicitly to find an all-inclusive strategy. This strategy has, instead, become a formal mandate for the new global communications department, although the focus of their social media actions is brand awareness.

Starting from these similarities and diversities and applying the boundary object lens, we can offer some suggestions concerning the roles and characteristics of objects in the occupational domain that are related to social media. Our results are specific to a particular time and setting, but they provide the ground for future research in a field that is expanding, including at academic level, and so crossing disciplinary boundaries.

\subsection{Boundary objects and hybridisation}

In this paper, we have endorsed the idea of boundary objects, seen as a valuable means for pursuing a more detailed account of practice (Pollock and Williams, 2015). By examining the actors and the production of their artefacts, we have analysed whether actors are more or less able to translate their ideas forcibly across organisational boundaries, and so gain occupational space. The two cases reveal a central artefact emerging as social media advance throughout an organisation: social media monitoring. We take this as a prime example of boundary objects constructed upon social media, in order to draw more general conclusions.

After an initial attempt to make use of standard tools acquired externally, both Art and Utility engaged in redesigning measurement tools. At Art, the redesigned tool initially took the form of small dots indicating the promotional actions included in the scheduling sales sheet. An additional sheet with links to web applications was later included, which meant that the actions and reactions could be monitored in real time. At Utility, social media monitoring initially, during the first phase, consisted of a structured set of reports tailored to each department served by the Digital team. Using the online system, these reports were integrated within Digital department. During the second phase, each department gained ownership of department-specific reporting, together with all associated social mediarelated actions, while aspects relating to the overall monitoring process and to brand and reputation were replaced with web-based commercial solutions.

Although there are variations in the end propositions, the artefacts deployed all display a driving phenomenon, that of hybridisation. In order to improve the instrument and capture the attention of different actors, social media monitoring was progressively expanded to include elements derived from other reports or based upon ideas proposed by the managers with whom the social media owner had interacted. The hybridisation process followed different paths. The first concerned the content, and this led to the construction of hybrid indicators. Pure social media indicators, such as "nos of likes" and "sentiment", were soon abandoned at both Art and Utility, because managers considered them as conceptually distant or even alien to their business. The cases revealed that, with the hybridisation of content, the actors and the techniques developed during the process progressively acquired greater significance within the organisation, leading to connections being created between the new social media variables (e.g. nos of likes and sentiment) and the traditional business variables (e.g. revenue and customer satisfaction). 
Hybridisation was pursued by using mixed indicators, such as the ratio between sentiment on social media/theatre occupation for Art, and by introducing more refined statistical analyses, such as the correlation between changes to the social media indicators (followers) and changes in customer satisfaction, with respect to the different temporal gaps between the two variables. The owners of the social media monitoring were also able to introduce different forms of hybridisation for their artefacts at different points of the organisation. To explain, when actors are in search of top level, vertical engagement, the objects must establish a connection with financial data, both present and future. Because of these links, the aspect of monitoring social media becomes more tangible, outlining the possibility that a "like" on Facebook can lay the ground for further sales (see Art), or for an increase in share value (see Utility). The possibilities in terms of business development caught the attention of first line managers and then CEOs. The most visible output of the hybridisation path was the personalised dashboard, presenting synthetic information that is easy to communicate, and was put together after careful analysis and choice of information to display. In contrast, horizontal engagement, understood as a department's relationship with other departments, was achieved through a different form of hybridisation. This was more visible in Utility, especially during the first phase, when the Digital team provided a centralised service involving social media-based actions and social media reporting on these actions. Here, the feature that led to boundaries being crossed was flexibility: every department wanted to personalise the artefacts for their own use.

The actors also engaged upon a second hybridisation path, which in turn became a feature of the boundary object, hybridisation of reporting, which has a direct impact on the managers' decision making and actions. The process drew on two elements in particular, time and visual language. Regarding time, at the beginning, the social media owners in both organisations found the possibility of receiving daily or even real-time data very appealing. A key element of social media is in fact the immediate effect between what is controlled (social media) and the indicators (REF). The loop between action and results is shorter: a message can be uploaded in seconds and only a few more are needed for an organisation to see the reaction. In addition, social media are in themselves an artefact and can easily lead to further actions being taken. Once the boundaries are crossed and organisational actors can see the results, they are more likely to try things out for themselves, such as suggesting the type of content to be published, the users to be addressed and even the timing of the posts.

However, while social media is instantaneous in its timing, the managers interested in social media data faced differently timed needs. This path to personalise timing was harder and consisted of a true hybridisation process in which the social media owners interacted with the managers, entering into the merit of their decision-making cycles and understanding how social media data could potentially contribute to the process. The second feature of hybridisation in the reporting process concerned the visual language. Social media and Big Data have progressed alongside the developments in digital visualisation tools (Keim et al., 2013; Wang et al., 2015) where users can see trends and explore data in real time, sometimes down to the individual detail. In both cases examined, there was a hybridisation of languages. On the one hand, traditional variables entered into the digital monitoring tools, taking, for example, the form of timelines for promotions or launches of services; on the other hand, new graphs and visualisation devices entered into the traditional reporting schemes, for instance the visualisation of recurrent themes and heat maps.

Summarising, the governance of social media went through the phase of creating hybridised objects which could catalyse attention on social media, thereby ensuring that social media monitoring and the owners of such monitoring both gained in significance. This hybridisation is visible in the content (indicators and statistical analysis) and in the reporting, providing a first pathway into the world of Big Data. Because of the different forms that these hybrid objects assumed over time within the two organisations, we can 
make further considerations concerning their diversity and the extent to which they favour or inhibit the translation process performed by the social media owners (Latour, 1984) and whether they are capable of involving more or fewer actors.

\subsection{Engagement and object diversity}

Art and Utility experimented with different hybrid artefacts in order to share the importance of social media within the organisation to gain legitimisation (Caglio, 2003) and, above all, to understand the real value of social media. Although the results are specific to this time and place, in this section we have elaborated on the translation process and the effectiveness of the various boundary objects. The enabling function of boundary objects was identified by Carlile (2002), who defined three features describing "effective boundary objects" (Carlile, 2002, p. 451). In first place, objects should establish a shared language that individuals can use to express their knowledge; in second place, artefacts expressing worries have to be concrete; and in third place, effectiveness may be related to the actor's possibility of transforming their knowledge. This distinction was taken forward by Fox (2011), who highlighted a relationship between the facilitating and inhibitory objects and, in particular, what they mean to the actors involved. By comparing our two cases, we can elaborate further on this relationship, with middle-of-the-way considerations about management accounting on the social media transformation.

Our study confirms Fox's (2011) result whereby the object's meaning is central to establishing connections between communities. Our study also highlights a specific element relating to social medial accounting. This boundary object is the representation of an artefact, social media, which could itself be considered as a boundary object. However, the "rules" of governance in play are different. Social media are an open network where every person can post comments simple by having an internet connection. By entering the realm of social media, companies take the positive decision to be active in a virtual place, in the form of a conversation platform between users inside and outside their organisation. In our cases, the inside-outside link acted as an immediate meaning-stimulator for organisational actors interested in engaging with external users, especially the marketing and communication managers. The initial incentive to adopt social monitoring was driven by the new opportunities for getting to know their customers and speeding the decision-making cycle. In both cases, unfortunately, the standardised tools purchased proved to be unsatisfactory. In the case of Art, the tool was seen as too simple and rigid, with no possibility of acquiring or transferring knowledge (Carlile, 2002). In Utility, the tool was almost too complex and inhibited its potential users. While the marketing and communications managers were keen to gain the additional knowledge about their community, the effort required to upscale or downscale the tool's functions severely limited its usage.

This scepticism and non-use of data together integrate, and in part oppose, the recent discussion by Quattrone (2016) on the digital revolution. According to Quattrone (2016), there is a very real risk that the digital revolution may ultimately lead to losing the space where decision makers form their opinions and come to conclusions about taking action:

In this context of "big data" and spurious correlations, the appeal to the visual power of numbers as digits is increasing (Davison, 2015) with visualizations that become more and more convincing augmenting the already magic persuasive power of accounting numbers, with predictive models now making decisions and thus limiting the space for judgment to the very last, and short, part of the relationship between knowledge and action (Quattrone, 2016, p. 120).

In contrast with Quattrone's discussion (2016), our cases do not reveal blind decision makers but, on the contrary, users who abandon tools which they have not completely understood. The type of engagement with corporate managers pursued by the social media owner is, in our cases, similar to a collective path running between knowledge and action 
(Quattrone, 2016). In Art, this path followed a more hierarchical route. By bringing social media and their associated monitoring processes to executive meetings, the social media owner forced upper management to reflect on the strategic value of social media for their organisation, on the proper measures to control them, and on the consequent actions to introduce in cascade throughout the organisation. A central facilitating boundary object emerged, and this was progressively integrated with social media indicators: in the case of Art, scheduling. With regards to Utility, in the first phase there was, instead, a dispersed translation process, in which the initiator worked with the managers to construct tools appropriate to the business-specific needs of each.

To summarise, we suggest that the effectiveness of boundary objects in the age of social media is seminally linked to a company's willingness to connect with external stakeholders and to the value-added assigned by each department and at corporate level to social media. It may make sense to seek for a single answer, whilst also carrying out a search in parallel for a holistic boundary object to control this goal. Alternatively, different meanings can be set out that rely on constructing a portfolio of objects that must be both concrete and flexible.

\subsection{Rationality and community}

A final consideration can be made about boundary objects as epistemic entities. As shown in other studies, artefacts encompass and transmit the knowledge belonging to the actors governing them (Bechky, 2003; Jarzabkowski and Kaplan, 2015; Anteby et al., 2016; Marheineke et al., 2016). There is, however, no evidence concerning the degree to which the translation taking place during the negotiation process was able to change the rationality within the organisation with regards to the object (Rose and Miller, 1992). Our findings show that rationality is challenged during translations. This is evident at Art, where both social media and relative artefacts are initially constructed around a "market"-type rationality (Adler, 2001). It is, however, the case that the results of social media monitoring - low engagement - led the organisational actors to reflect upon the role of the digital community and even on that of Art, in the desire to create a wider space for their cultural role and a more genuine relationship with the outside world. This is similar to a move towards a "community"-type rationality, based on trust rather than simply between seller and buyer (Adler, 2001). In Utility, the process was the reverse. The initial experiment was to link the "outside with the inside", which entailed a "community"type rationality. The increase in interest across the organisation led to adding further purposes to social media, where a "market" logic prevailed, although social media governance was still in the hands of the initiator. With the change in governance, a third "hierarchical" rationality started to emerge, where the regulation of operations was linked to authority. Although the new head of communications stated that his aspiration was to build an inside-outside network, that was to include Utility "ambassadors", he implemented a hierarchical-type strategy, with strict rules for each branch, department and employee.

\section{Conclusions}

Social media is a reality in both profit and non-profit organisations (Kaplan and Haenlein, 2010; Gopinath et al., 2014). Often originating in the fields of marketing and communication, social media are now widely used throughout any organisation (Field and Chelliah, 2012; Trainor et al., 2014; Hennig-Thurau et al., 2015), affecting nearly all the departments with their dual function. First, it is a tool for global, instant and multi-way communication; and second, it can potentially provide information at the lowest, individual level, without the need to make use of surveys or questionnaires. The consultancy industry and entrepreneurs alike have been keen to seize the opportunities emanating from the business world's enthusiastic interest in developing services and tools built around social media. There are still, however, limited academic contributions dealing with the organisational impact of these technology platforms, in particular with regards to their impact on accounting, although social 
media monitoring has vehemently entered the sphere of performance management. In this paper, we have concentrated on a specific aspect, that of the occupational transformation that relates to this new field. We have explored how organisational actors define new tasks and change their occupational boundaries, thriving on the opportunity to manage social media and the associated information that can be so obtained. Drawing on the seminal contribution of Star and Griesemer (Star, 1989; Star and Griesemer, 1989), we analysed two empirical cases, Art and Utility, explored through the theoretical lens of the boundary object literature. By adopting this frame, we were able to reach more general conclusions and so contribute to previous studies and stimulate further research.

Our contribution involves the large and lively stream of studies concerned with the professional and occupational adoption of the boundary object lens (Bechky, 2003; Jarzabkowski and Kaplan, 2015; Anteby et al., 2016; Marheineke et al., 2016). We have highlighted a driving phenomenon that is emerging in the surge to occupy the organisational terrain for controlling social media: that of hybridisation. The concept of hybridisation is not new in management accounting studies having been used to interpret and explain the changes in expertise required by accountants and their role in the face of innovation, in particular concerning information technology (Caglio, 2003; Kurunmäki, 2004; Dechow and Mouritsen, 2005; Miller et al., 2008; Chapman and Kihn, 2009). However, in this study, we have fused the concept of hybridisation into the interpretation of boundary objects, opening broader theoretical considerations. As highlighted by Fox (2011), studies on boundary objects have mostly focused on analysing the types of objects concerned, adding categories to the original work of Star and colleagues (Star, 1989, 2010; Star and Griesemer, 1989; Bowker and Star, 1999). A smaller number of studies have, instead, investigated their uses and effectiveness in relation to organisational proceedings. The concept of hybridisation is a theoretical lens that allows a joint analysis to be carried out on both the boundary objects and their organisational trajectory. In the context of social media accounting, hybridisation is central for both the actors and the objects to be effectively positioned at the boundary. Flexibility, materiality and granularity (Star and Griesemer, 1989) have emerged not merely as abstract characteristics belonging to objects, but are seen as the result of a translation pathway (Latour, 1987), in which actors engage in a collective process of knowledge.

Social media owners enter the managers' decision-making cycle and managers enter the complex cycle of social media data processing. Through the unfolding of where and how social media data are useful, all actors must and do hybridise their knowledge, therefore contributing towards creating more effective objects. This, in turn, exposes the complexity of the relationship between human beings and data in the digital era (Bhimani and Willcocks, 2014; Suddaby, Bruton and Si, 2015; Suddaby, Saxton and Gunz, 2015). Our results found also that a strict relation exists between the boundary properties of objects and participation, unfolding new questions for future studies. We can ask whether this strict relationship is linked to the novelty of this development in organisations or does Big Data entail a complexity such that data owners and managers are in continuous discussion? This question does not only concern scholars, but also affects practitioners, and accountants in particular.

A final consideration must be made in connection with accountants. This study reveals that accountants are particularly reluctant when it comes to social media. Accountants can often feel that social media, and the way in which social media information is managed, are a matter for marketing and communications, considering the topic to be of marginal use in terms of developing business. The impact of social media on business value is still uncertain, but it is clear that boundary objects constructed upon social media can certainly capture the attention of senior executives and middle management. As a further point, by engaging in boundary spanning work (Levina and Vaast, 2005), social media monitoring owners can gain new and dynamic capabilities. This aspect potentially can, in turn, mean that, in the future, accountants may find themselves relegated to carrying out routine work, with the work of exploration being left in the hands of other people. 


\section{Notes}

1. Examples of new associations for social media managers: www.socialmediamanagersassociation.com/; www.socialmediatoday.com/content/global-social-media-managers-associationtm-now-live

2. www.salesforce.com/

3. This phase continued during the paper review process and we are grateful to reviewers for suggestions in improving our theoretical contribution.

\section{References}

Abeyesekera, N. (2015), "Delivering value through business transformation in the digital age", Edge, CIMA, October-November.

Adler, P.S. (2001), "Market, hierarchy, and trust: the knowledge economy and the future of capitalism", Organization Science, Vol. 12 No. 2, pp. 215-234.

Alin, P., Iorio, J. and Taylor, J.E. (2013), "Digital boundary objects as negotiation facilitators: spanning boundaries in virtual engineering project networks", Project Management Journal, Vol. 44 No. 3, pp. 48-63.

America Marketing Association (2016), "Professional development in the social media age", available at: www.ama-pdx.org

Anteby, M., Chan, C.K. and DiBenigno, J. (2016), "Three lenses on occupations and professions in organizations: becoming, doing, and relating", The Academy of Management Annals, Vol. 10 No. 1, pp. 183-244.

Arora, P., Owens, D. and Khazanchi, D. (2010), "A pattern-based tool for knowledge management in virtual projects", IUP Journal of Knowledge Management, Vol. 8 No. 3, pp. 60-80.

Bechky, B.A. (2003), "Object lessons: workplace artifacts as representations of occupational jurisdiction1", American Journal of Sociology, Vol. 109 No. 3, pp. 720-752.

Berthon, P.R., Pitt, L.F., Plangger, K. and Shapiro, D. (2012), "Marketing meets web 2.0, social media, and creative consumers: implications for international marketing strategy", Business Horizons, Vol. 55 No. 3, pp. 261-277.

Bhimani, A. and Willcocks, L. (2014), "Digitisation, 'Big Data' and the transformation of accounting information", Accounting and Business Research, Vol. 44 No. 4, pp. 469-490.

Biernacki, P. and Waldorf, D. (1981), "Snowball sampling: problems and techniques of chain referral sampling”, Sociological Methods \& Research, Vol. 10 No. 2, pp. 141-163.

Bologva, E.V., Prokusheva, D.I., Krikunov, A.V., Zvartau, N.E. and Kovalchuk, S.V. (2016), "Humancomputer interaction in electronic medical records: from the perspectives of physicians and data scientists", Procedia Computer Science, Vol. 100 No. 2016, pp. 915-920.

Booth, A., Mohr, N. and Peters, P. (2016), The Digital Utility: New Opportunities and Challenges, McKinsey Insights.

Bowker, G. and Star, S.L. (1999), Sorting Things Out. Classification and its, The MIT Press, Cambridge, $\mathrm{MA}$ and London.

Boyd, N. and Gessner, B. (2013), "Human resource performance metrics: methods and processes that demonstrate you care", Cross Cultural Management: An International Journal, Vol. 20 No. 2, pp. 251-273.

Brown, N.C., Stice, H. and White, R.M. (2015), "Mobile communication and local information flow: evidence from distracted driving laws", Journal of Accounting Research, Vol. 53 No. 2, pp. 275-329.

Bruhn, M., Schoenmueller, V. and Schafer, D.B. (2012), "Are social media replacing traditional media in terms of brand equity creation?", Management Research Review, Vol. 35 No. 9, pp. 770-790. 
Caglio, A. (2003), "Enterprise resource planning systems and accountants: towards hybridization?", European Accounting Review, Vol. 12 No. 1, pp. 123-153.

Cao, S. and Manrai, A.K. (2014), "Big data in marketing \& retailing", Journal of International \& Interdisciplinary Business Research, Vol. 1, Spring, pp. 23-42.

Carlile, P.R. (2002), "A pragmatic view of knowledge and boundaries: boundary objects in new product development”, Organization Science, Vol. 13 No. 4, pp. 442-455.

Chapman, C.S. and Kihn, L.A. (2009), "Information system integration, enabling control and performance", Accounting, Organizations and Society, Vol. 34 No. 2, pp. 151-169.

Chartered Institute of Management Accounting (2016), " 8 ways to ... Use social media” Richard Young, available at: www.fm-magazine.com/feature/list/8-ways-use-social-media

Chikandiwa, T.S., Contogiannis, E. and Jembere, E. (2013), "The adoption of social media marketing in South African banks", European Business Review, Vol. 25 No. 4, pp. 365-381.

CIMA (2011), "Sustainability and the role of the management accountant", Research Executive Summary Series, available at: www.cimaglobal.com

Comuzzi, M. and Patel, A. (2016), "How organisations leverage big data: a maturity model", Industrial Management \& Data Systems, Vol. 116 No. 8, pp. 1468-1492, doi: 10.1108/imds-122015-0495.

Constantinides, E. (2014), "Foundations of social media marketing", Procedia - Social and Behavioral Sciences, Vol. 148, pp. 40-57.

Dechow, N. and Mouritsen, J. (2005), "Enterprise resource planning systems, management control and the quest for integration”, Accounting, Organizations and Society, Vol. 30 No. 7, pp. 691-733.

Denzin, N.K. (1978), The Research Act: A Theoretical Introduction to Sociological Methods, 2nd ed., McGraw-Hill, New York, NY.

Dumeresque, D. (2014), "The chief digital officer: bringing a dynamic approach to digital business", Strategic Direction, Vol. 30 No. 1, pp. 1-3.

Eschenbrenner, B., Nah, F.F.H. and Telaprolu, V.R. (2014), "Efficacy of social media utilization by public accounting firms: findings and directions for future research", Journal of Information Systems, Vol. 29 No. 2, pp. 5-21.

Fenton, E.M. (2007), "Visualising strategic change: the role and impact of process maps as boundary objects in reorganisation”, European Management Journal, Vol. 25 No. 2, pp. 104-117.

Field, J. and Chelliah, J. (2012), "Social-media misuse a ticking time-bomb for employers: robust policies and procedures needed to reduce the risks", Human Resource Management International Digest, Vol. 20 No. 7, pp. 36-38.

Fitzgerald, M. (2012), "Juggling ICT's social media's roles (the role of ICT professionals in an organization's social media strategy)", Strategic Direction, Vol. 28 No. 7.

Floreddu, P.B., Cabiddu, F. and Evaristo, R. (2014), "Inside your social media ring: how to optimize online corporate reputation", Business Horizons, Vol. 57 No. 6, pp. 737-745.

Fox, N.J. (2011), "Boundary objects, social meanings and the success of new technologies", Sociology, Vol. 45 No. 1, pp. 70-85.

Gamboa, A.M. and Goncalves, H.M. (2014), "Customer loyalty through social networks: lessons from Zara on Facebook", Business Horizons, Vol. 57 No. 6, pp. 709-717.

Gandomi, A. and Haider, M. (2015), "Beyond the hype: big data concepts, methods, and analytics", International Journal of Information Management, Vol. 35 No. 2, pp. 137-144.

Gopinath, S., Thomas, J.S. and Krishnamurthi, L. (2014), "Investigating the relationship between the content of online word of mouth, advertising, and brand performance", Marketing Science, Vol. 3 No. 2, pp. 241-258.

Gruber, D.A., Smerek, R.E., Thomas-Hunt, M.C. and James, E.H. (2015), "The real-time power of Twitter: crisis management and leadership in an age of social media", Business Horizons, Vol. 58 No. 2, pp. 163-172. 
Guinan, P.J., Parise, S. and Rollag, K. (2014), "Jumpstarting the use of social technologies in your organization”, Business Horizons, Vol. 57 No. 3, pp. 337-347.

Habibi, M.R., Laroche, M. and Richard, M.O. (2014), "Brand communities based in social media: how unique are they? Evidence from two exemplary brand communities", International Journal of Information Management, Vol. 34 No. 2, pp. 123-132.

Haefliger, S., Monteiro, E., Foray, D. and von Krogh, G. (2011), "Social software and strategy", Long Range Planning, Vol. 44 No. 5, pp. 297-316.

Haislip, J.Z., Peters, G.F. and Richardson, V.J. (2016), "The effect of auditor IT expertise on internal controls", International Journal of Accounting Information Systems, Vol. 20, pp. 1-15.

Hartmann, P.M., Zaki, M., Feldmann, N. and Neely, A. (2016), "Capturing value from big data a taxonomy of data-driven business models used by start-up firms", International Journal of Operations \& Production Management, Vol. 36 No. 10, pp. 1382-1406.

Hennig-Thurau, T., Wiertz, C. and Feldhaus, F. (2015), "Does Twitter matter? The impact of microblogging word of mouth on consumers' adoption of new movies", Journal of the Academy of Marketing Science, Vol. 43 No. 3, pp. 375-394.

Hsiao, R.L., Tsai, D.H. and Lee, Ch.F. (2012), "Collaborative knowing: the adaptive nature of crossboundary spanning”, Journal of Management Studies, Vol. 49 No. 3, pp. 463-491.

IBM (2014), Harness the Power of Big Data (The IBM Big Data Platform), ISBN: 978-0-07180818-7, The McGraw-Hill Companies.

IMA (2015), "Building a team to capitalize on the promise of big data", Robert Half Study, available at: www.imanet.org

Jarzabkowski, P. and Kaplan, S. (2015), "Strategy tools-in-use: a framework for understanding 'technologies of rationality' in practice”, Strategic Management Journal, Vol. 36 No. 4, pp. 537-558.

Jeacle, I. and Carter, C. (2014), "Creative spaces in interdisciplinary accounting research", Accounting, Auditing \& Accountability Journal, Vol. 27 No. 8, pp. 1233-1240.

Jin, S.A. (2012), "The potential of social media for luxury brand management", Marketing Intelligence \& Planning, Vol. 30 No. 7, pp. 687-699.

Jonsen, K. and Jehn, K.A. (2009), "Using triangulation to validate themes in qualitative studies", Qualitative Research in Organizations and Management: An International Journal, Vol. 4 No. 2, pp. 123-150.

Kane, G.C., Palmer, D., Phillips, A.N., Kiron, D. and Buckley, N. (2015), Strategy, Not Technology, Drives Digital Transformation. Becoming a Digitally Mature Enterprise, Deloitte University Press, pp. 1-25.

Kaplan, A.M. and Haenlein, M. (2010), "Users of the world, unite! The challenges and opportunities of social media”, Business Horizons, Vol. 53 No. 1, pp. 59-68.

Keim, D., Qu, H. and Ma, K.L. (2013), "Big-data visualization”, IEEE Computer Graphics and Applications, Vol. 33 No. 4, pp. 20-21.

Kietzmann, J.H., Hermkens, K., McCarthy, I.P. and Silvestre, B.S. (2011), "Social media? Get serious! Understanding the functional building blocks of social media”, Business Horizons, Vol. 54 No. 3, pp. 241-291.

Kotb, A., Roberts, C. and Sian, S. (2012), "E-business audit: advisory jurisdiction or occupational invasion?”, Critical Perspectives on Accounting, Vol. 23 No. 6, pp. 468-482.

Kurunmäki, L. (2004), "A hybrid profession - the acquisition of management accounting expertise by medical professionals", Accounting, Organizations and Society, Vol. 29 No. 3, pp. 327-347.

Latour, B. (1984), “The powers of association”, The Sociological Review, Vol. 32 No. S1, pp. 264-280.

Latour, B. (1987), Science in Action: How to Follow Scientist and Engineers through Society, Harvard University Press, Cambridge, MA. 
Levina, N. and Vaast, E. (2005), "The emergence of boundary spanning competence in practice: implications for implementation and use of information systems”, MIS Quarterly, Vol. 29 No. 2, pp. 335-363.

Li, J. and Robertson, T. (2011), "Physical space and information space: studies of collaboration in distributed multidisciplinary medical team meetings", Behaviour \& Information Technology, Vol. 30 No. 4, pp. 443-454.

Manetti, G. and Bellucci, M. (2016), "The use of social media for engaging stakeholders in sustainability reporting", Accounting, Auditing \& Accountability Journal, Vol. 29 No. 6, pp. 985-1011.

Marheineke, M., Velamuri, V.K. and Möslein, K.M. (2016), "On the importance of boundary objects for virtual collaboration: a review of the literature”, Technology Analysis \& Strategic Management, pp. 1-15.

Miller, G.S. and Skinner, D.J. (2015), "The evolving disclosure landscape: how changes in technology, the media, and capital markets are affecting disclosure", Journal of Accounting Research, Vol. 53 No. 2, pp. 221-239.

Miller, P., Kurunmäki, L. and O'Leary, T. (2008), "Accounting, hybrids and the management of risk", Accounting, Organizations and Society, Vol. 33 No. 7, pp. 942-967.

Neill, M.S. and Moody, M. (2015), "Who is responsible for what? Examining strategic roles in social media management", Public Relations Review, Vol. 41 No. 1, pp. 109-118.

Ngai, E.W., Tao, S.S. and Moon, K.K. (2015), "Social media research: theories, constructs, and conceptual frameworks", International Journal of Information Management, Vol. 35 No. 1, pp. 33-44.

Noy, C. (2008), "Sampling knowledge: the hermeneutics of snowball sampling in qualitative research", International Journal of Social Research Methodology, Vol. 11 No. 4, pp. 327-344.

Oakes, H. and Oakes, S. (2016), "Accounting colonisation and austerity in arts organisations”, Critical Perspectives on Accounting, Vol. 38, July, pp. 34-53.

Orlikowski, W.J. (2007), "Sociomaterial practices: exploring technology at work", Organization Studies, Vol. 28 No. 9, pp. 1435-1448.

Pollock, N. and Williams, R. (2015), "Industry analysts - how to conceptualise the distinctive new forms of IT market expertise?”, Accounting, Auditing \& Accountability Journal, Vol. 28 No. 8, pp. 1373-1399.

Quattrone, P. (2016), "Management accounting goes digital: will the move make it wiser?", Management Accounting Research, Vol. 31, June, pp. 118-122.

Rathwell, K., Armitage, D. and Berkes, F. (2015), "Bridging knowledge systems to enhance governance of environmental commons: a typology of settings", International Journal of the Commons, Vol. 9 No. 2.

Richardson, A.J. (2009), "Regulatory networks for accounting and auditing standards: a social network analysis of Canadian and international standard-setting", Accounting, Organizations and Society, Vol. 34 No. 5, pp. 571-588.

Roblek, V., Bach, M.P., Meško, M. and Bertoncelj, A. (2013), "The impact of social media to value added in knowledge-based industries", Kybermetes, Vol. 42 No. 4, pp. 554-568.

Rose, N. and Miller, P. (1992), "Political power beyond the state: problematics of government", British Journal of Sociology, Vol. 43, pp. 173-205.

Rust, R.T. and Huang, M.H. (2014), "The service revolution and the transformation of marketing science”, Marketing Science, Vol. 33 No. 2, pp. 206-221.

Saparova, D., Kibaru, F. and Bašić, J. (2013), "Use of widgets as information management tools in online shared spaces”, International Journal of Information Management, Vol. 33 No. 2, pp. 401-407.

Scholz, J. and Smith, A.N. (2016), "Augmented reality: designing immersive experiences that maximize consumer engagement”, Business Horizons, Vol. 59 No. 2, pp. 149-161.

Star, S.L. (1989), "The structure of ill-structured solutions: heterogeneous problem-solving, boundary objects and distributed artificial intelligence", Distributed Artificial Intelligence, Vol. 2, pp. 37-54. 
Star, S.L. (2010), "This is not a boundary object: reflections on the origin of a concept", Science, Technology \& Human Values, Vol. 35 No. 5, pp. 601-617.

Star, S.L. and Griesemer, J.R. (1989), "Institutional ecology, translations' and boundary objects: amateurs and professionals in Berkeley's Museum of Vertebrate Zoology, 1907-39", Social Studies of Science, Vol. 19 No. 3, pp. 387-420.

Suddaby, R., Bruton, G.D. and Si, S.X. (2015), "Entrepreneurship through a qualitative lens: insights on the construction and/or discovery of entrepreneurial opportunity", Journal of Business Venturing, Vol. 30 No. 1, pp. 1-10.

Suddaby, R., Saxton, G.D. and Gunz, S. (2015), "Twittering change: the institutional work of domain change in accounting expertise", Accounting, Organizations and Society, Vol. 45, August, pp. 52-68.

Swani, K., Brown, B.P. and Milne, G.R. (2014), "Should tweets differ for B2B and B2C? An analysis of Fortune 500 companies' Twitter communications”, Industrial Marketing Management, Vol. 43 No. 5 , pp. 873-881.

Szabo, L.-V. (2014), "The future of communication: from new media to postmedia”, Procedia - Social and Behavioral Sciences, Vol. 163, December, pp. 36-43.

Tench, R. and Jones, B. (2015), "Social media: the wild west of CSR communications", Social Responsibility Journal, Vol. 11 No. 2, pp. 290-305.

Tiago, M.T.P.M.B and Veríssimo, J.M.C. (2014), "Digital marketing and social media: why bother?", Business Horizons, Vol. 57 No. 6, pp. 703-708.

Ting, I.-H. (2015), "Developing analytic talent: becoming a data scientist", Online Information Review, Vol. 39 No. 2, pp. $273-273$.

Toledano, M. (2010), "Professional competition and cooperation in the digital age: a pilot study of New Zealand practitioners", Public Relations Review, Vol. 36 No. 3, pp. 230-237.

Trainor, K.J., Andzulis, J.M., Rapp, A. and Agnihotri, R. (2014), "Social media technology usage and customer relationship performance: a capabilities-based examination of social CRM", Journal of Business Research, Vol. 67 No. 6, pp. 1201-1208.

Tymms, A., Simmons, R. and Zecha, J. (2016), “Measuring a company's digital competence”, Bain Brief, pp. 1-5.

Valos, M.J., Haji Habibi, F., Casidy, R., Driesener, C.B. and Maplestone, V.L. (2016), "Exploring the integration of social media within integrated marketing communication frameworks", Marketing Intelligence \& Planning, Vol. 34 No. 1, pp. 19-40.

van Dam, J.W. and van de Velden, M. (2015), "Online profiling and clustering of Facebook users", Decision Support Systems, Vol. 70, Febraury, pp. 60-72.

Wang, L., Wang, G. and Alexander, C.A. (2015), "Big data and visualization: methods, challenges and technology progress”, Digital Technologies, Vol. 1 No. 1, pp. 33-38.

Wang, X., Love, P.E., Kim, M.J. and Wang, W. (2014), "Mutual awareness in collaborative design: an augmented reality integrated telepresence system", Computers in Industry, Vol. 65 No. 2.

Wright, D. and Hinson, M. (2012), "Examining how social and emerging media have been used in public relations between 2006 and 2013: a longitudinal analysis", Institute for Public Relations, available at: www.instituteforpr.org

Zamora, D., Barahona, J.C. and Palaco, I. (2016), “Case: digital governance office”, Journal of Business Research, Vol. 69 No. 10, pp. 4484-4488. 